\title{
Accounting
}

\section{Solutions to attract investment capital for tourism development: Evidence from Vietnam economy}

\author{
Huyen Le Hoang Ba ${ }^{a}$, Phuong Nguyen Thi Thu ${ }^{a}$, Thanh Ngo Chi ${ }^{a^{*}}$, Chinh Le Huy and Hanh \\ Hoang Thanh ${ }^{b}$
}

\author{
${ }^{a}$ Hong Duc University, Vietnam \\ ${ }^{b}$ Academy of Finance, Vietnam

\section{H R O N I C L E} \\ Article history: \\ Received September 22019 \\ Received in revised format \\ September 2019 \\ Accepted October 152019 \\ Available online \\ October 152019 \\ Keywords: \\ Investment attraction \\ Tourism development \\ Thanh Hoa
}

\begin{abstract}
A B S T RA C T
The objective of this study is to propose solutions to attract investment capital for tourism development in Thanh Hoa province, Vietnam. Based on the theoretical framework following eclectic or "OLI model" developed by Dunning and Narula (1996) [Dunning, J., \& Narula, R. (2003). Foreign direct investment and governments: catalysts for economic restructuring. Routledge.] and data of 660 questionnaires collected from a survey of tourism investors in Thanh Hoa provinces, we found some important influential factors affecting the attraction of investment for tourism development in Thanh Hoa province. In particular, the local government's policy of attracting capital appears to have the highest level of importance. The study has some policy implications to increase the attractiveness of investment capital in tourism development in the area.
\end{abstract}

\section{Introduction}

The topic of attracting investment capital for socio-economic development in general and tourism in particular has received the attention of both scholars and practitioners (Nguyen et al., 2019b). The scientific works in this field are quite diverse with different findings depending on the approach (Gupta et al., 2003). Research projects on capital mobilization for tourism development are mainly divided into two groups; namely, group of research projects on mobilizing investment capital for tourism development for a region and group of research projects on mobilizing investment capital for tourism development for a specific locality (Rankin, 2002). According to Nguyen et al. (2019a), detecting important factors influencing the profitability of tourism business activities gives some insight to increase the efficiency of tourism business. They performed a survey in BinhDinh, Vietnam and grouped different factors influencing the industry. Tung (2019) examined the effect of exchange rate policy on foreign tourist arrivals in Vietnam over the period 2006-2018. They reported that the exchange rate maintained a positive effect on the demand of foreign tourists. Anh et al. (2019) developed a model to measure the effect of user's perception on user-generated tourism content and reported that that the perceived usefulness indirectly influenced user-generated content through electronic word of mouth (eWOM), attitudes of visitors when choosing destinations and attitudes when implementing media social communication. Tran et al. (2019) measured the level of economic linkage in key economic zones in central Vietnam generally and measured the effect of economic linkage in the tourism sector. Anh et al. (2020) determined the effects

* Corresponding author.

E-mail address: ngochithanh@hdu.vn (T. N. Chi) 
of tangibles, assurance, empathy, reliability and responsiveness on repurchase intention among tourisms who visited Vietnam. Donwa and Odia (2010) performed an analysis on the effect of the Nigerian capital market on socio-economic development. They advised to put up measures to stem up investors' confidence and activities in the market so that it could help the Nigerian socio-economic development. Ewah et al. (2009) investigated the appraisal of capital market efficiency on economic growth in Nigeria. It can be said that in various aspects, recent research projects have analyzed quite comprehensive financial management mechanism, policies to mobilize investment capital for tourism development. The number of research projects is quite large and they concentrate on many aspects of financial management, budget management, investment capital for tourism development, etc. However, to the best of our knowledge, there is no comprehensive research project on the solution to attract capital for tourism development, especially the policy solutions of provincial authorities and no solutions for attracting investment capital in the direction of ensuring the condition of financial resources to ensure the quality of the local tourism industry. In order to guarantee sufficient financial capacity for local tourism development, in the context of limited state budget, the requirement to ensure the quality of tourism services and tourism infrastructure is urgent. This study aims to fill this gap in the literature.

\section{Model and research methodology}

\subsection{Model and research hypothesis}

This research is based on a theoretical framework derived from the eclectic model or the "OLI" model which is developed by Dunning (1996). In addition, this research is based on the theory of the factors influencing the selection of investment markets by Gilmore et al. (2003). Moreover, the authors have reviewed previous researches on attracting investment in a locality in Vietnam such as research by Nguyen (2010) on factors affecting foreign direct investment (FDI) in a locality in Vietnam including: Resource Motivation Group; Infrastructure Motivation Group; Policy Motivation Group and Economic Motivation Group. The research of Ha et al. (2013) on factors affecting the attraction of investment capital in Quang Tri province with nine factors including: decision making process related to investment procedures; Supportive policies from the management agencies related to investor; Technical infrastructure; Resources; Infrastructure of industrial parks and economic zones; Social infrastructure; Market potential; Cost advantage; Productivity and labor discipline.Based on the theoretical framework, the authors have selected five groups of factors to study their impacts on attracting investment capital outside the state budget for Thanh Hoa tourism development. In addition to four factors: tourism resources, capital attraction policies, infrastructure and economic factors that have been used in previous studies in other localities, the political-social factor has been added by Le and Nguyen (2017) in Thanh Hoa. Specifically: (1) Group of tourism resources (N), includes natural tourism resources (geographical location, topography, famous landscpae, etc.) and human tourism resources (tangible and intangible cultural resources). (2) Group of local government's capital mobilization policies (CP) such as tax incentives, interest rates, compensation policy for clearance, etc. (3) Group of Infrastructure (I) such as communications, transport, technology development, the development of legal services, accounting, etc. (4) Group of local socio-political factors (PS) includes the following: Unity within the local government; Political security and social safety of the locality; behavior culture of government with people and enterprises, (5) Group of local economic factors (E) such as economic growth, influence of domestic investment.

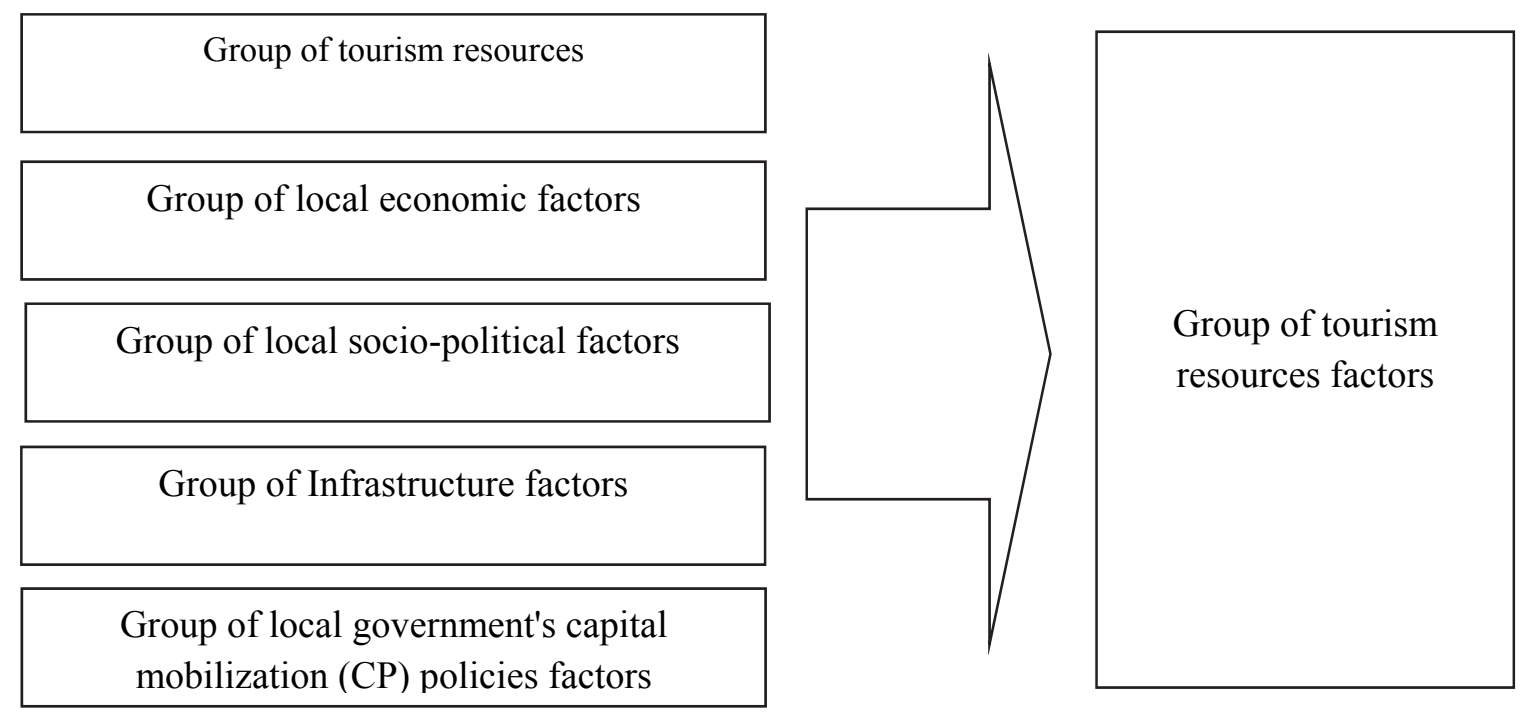

Fig. 1. Research model

[Source: Synthesis of authors] 
The general regression equation is: Capacity to attract investment outside the state budget for tourism development in Thanh Hoa province:

$\mathrm{Y}^{\prime}=\mathrm{f}$ (5 research factors: N, CP, I, PS, E ) The hypotheses of this research are as follows:

$\mathbf{H}_{01}$ : Tourism resources have a positive impact on the ability to attract investment capital for tourism development in Thanh Hoa province.

$\mathbf{H}_{02}$ : The policy to attract investment capital has a positive impact on the ability to attract investment capital for tourism development in Thanh Hoa province

Ho3: Infrastructure has a positive impact on the ability to attract investment capital for tourism development in Thanh Hoa province.

Ho4: The socio-economic stability has a positive impact on the ability to attract investment capital for tourism development in Thanh Hoa province.

Ho5: Economic factors have positive impacts on the ability to attract investment capital for tourism development in Thanh Hoa province.

\subsection{Description of the data}

(i) The object of this survey include investors on business, tourism services in Thanh Hoa province. This group of people will decide to invest. Therefore, their assessments will be the most accurate basis in determining the factors that affect the attraction of investment capital for tourism development.

(ii) Sampling method, the authors selected a convenient random method. This sampling method is selected because the authors had the ability to approach the respondents and they were willing to answer the research questionnaire; On the other hand it was less expensive and time consuming to collect research information.

(iii) The sample size was determined as 660 by Hoang Trong and Chu Nguyen Mong (2012); when analyzing factors and regression, the sample scale should be at least 5 times multiplied by the number of questionnaires. For the design questionnaire, the author was expected to receive answers for 30 questions; corresponding to a sample size of at least 150 . However, the research content is part of the research topic and also served many other research contents, thus, the authors conducted the survey for the whole 660 investors in the locality.

(iv) The scale used in this study was Likert for measuring survey questions with the following convention: (Level 5): Absolutely agree; (Level 4): Agree; (Level 3): No comments; (Level 2): Disagree; (Level 1): Absolutely disagree. Personal characteristics are combined to use a number of scales as identifiers for gender, cultural background.

(v) Questionnaire: For this study, the authors designed a questionnaire for tourism investors to determine the important factors affecting the attraction of investment. The design questionnaire consists of 5 parts: (1) Introduction; (2) Qualitative questions; (3) Warming questions; (4) key questions; (5) Additional question: After designing the questionnaire, 65 questionnaires were sent in advance to 65 respondents for asking their opinion again and also for editing the questionnaire for the last time before mass deployment.

\section{Research result}

\subsection{Results of exploratory analysis and testing of scale reliability}

Using SPSS 20.0 software to handle 30 variables, the authors excludes 6 variables CP6, CP7, I2, I6, PS4, E6 because the coefficients of variables are less than 0.3 , the remaining 24 observation variables of the five factorial groups had a Cronbach's Alpha coefficient greater than 0.6. In particular, the lowest was the $\mathrm{N}$ group with Alpha coefficient $=0.720$.

\section{Table 1}

Results of the scale reliability assessment

\begin{tabular}{llc}
\multicolumn{1}{c}{ Variable } & \multicolumn{1}{c}{ Key factors } & Conbach's Alpha \\
\hline N (Natural resources) & 5 Variables: N1, N2, N3, N4, N5 & 0.720 \\
CP (Capital policies) & 5 Variables: CP1, CP2, CP3, CP4, CP5 & 0.810 \\
I (Infrastructure) & 4 Variables: I1, I3, I4, I5 & 0.737 \\
PS (Politics - Society) & 4 Variables: PS1, PS2, PS3, PS5 & 0.787 \\
E (Economic) & 6 Variables: E1, E2, E3, E4, E5, E7 & 0.809 \\
\hline
\end{tabular}

[Source: Author's calculations]

The test results show that the scale used is consistent, correlative coefficients ranges from 0.3 and above (Nunnally, 1994). Therefore, these measurement variables are acceptable in terms of reliability and are used in EFA analysis. We have used Principal Component Analysis to extract Varimax for factor analysis. The factor loading must be greater than 0.5 to make practical sense. The results show that $\mathrm{KMO}=0.768>0.5$ : EFA factor analysis is well suited to research data. Bartlett's test result is 4903.207 with a significance level of $0.000<0.005$, indicating that the data used for the analysis is perfectly consistent. In addition, the factor loading that influences the attractiveness of investment capital is greater than 0.5 ; Eigenvalue value is greater than 1 and cumulative test variance $=55.813 \%$ (greater than $50 \%$ ), which indicates that these factors account for $55.813 \%$ of 
variance. The cumulative variance value satisfies the requirement. Thus, all independent variables in the research model after the removal of variables CP6, CP7, I2, I6, PS4, and E6 have convergent values and acceptable discriminant values. Factor analysis is appropriate for research data. Five factors were extracted from the results of the analysis, including 24 observations variables used for subsequent analysis.

\subsection{Analysis of factors affecting the ability to attract investment capital other than the state budget for tourism development in Thanh Hoa province}

With data obtained, the authors used the model of binary logistic regression for analysis. One of the conditions required for regression analysis is that the independent variable must correlate with the dependent variable, if not correlated, this type of independent variable is out of the regression analysis. Thus, before performing regression analysis, the authors examined the Pearson correlative coefficient to examine the linear relationship between variables independent of the dependent variable. The greater the correlative coefficient, the closer the correlation between the independent variable and the dependent variable.

Table 2

Correlative matrix between variables

\begin{tabular}{ccccccc}
\hline Variable & \multirow{2}{*}{ Ability to attract investment capital } & $\mathrm{I}$ & $\mathrm{N}$ & $\mathrm{CP}$ & $\mathrm{PS}$ & $\mathrm{E}$ \\
\hline Ability to attract investment capital & 1 & $.149^{* *}$ & $-.078^{*}$ & $.607^{* *}$ & $.150^{* *}$ & $.09^{* *}$ \\
I & $.149^{* *}$ & 1 & -.051 & -.025 & $.298^{* *}$ \\
N & $-.078^{*}$ & -.051 & 1 & $-.239^{* *}$ & $.150^{* *}$ & -.035 \\
CP & $.607^{* *}$ & -.025 & $-.239^{* *}$ & 1 & .027 & $.086^{*}$ \\
PS & $.150^{* *}$ & $.109^{* *}$ & $.150^{* *}$ & .027 & 1 & -.026 \\
E & .077 & $.298^{* *}$ & -.035 & $.086^{*}$ & -.026 \\
\hline
\end{tabular}

[Source: Processing results by SPSS software from survey data]

After running the correlative matrix, the factor $\mathrm{E}$ was found to be sig $=0.051>0.05$, it was not correlated with the ability to attract capital and the type $\mathrm{E}$ variable was removed from the model. The remaining variables have mainatined sigs $<0.05$ suitable for continued regression analysis. Results for binary logistic regression after removing variable $\mathrm{E}$ are shown in Table 3 as follows,

Table 3

Results for binary logistic regression model

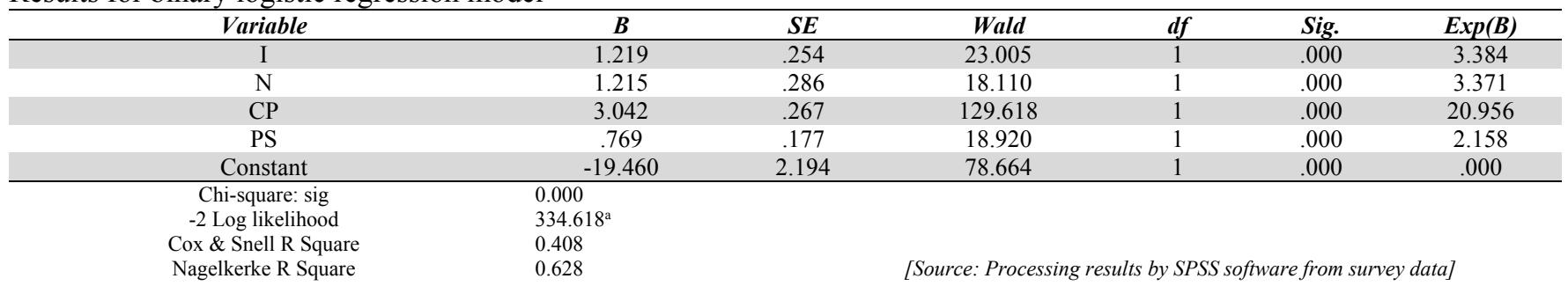

Based on the results in Table 8 , the Chi-squared test with the value sig $=0.00<0.05$ indicates the overall suitability of the model, the factors in the model have an impact on the decision of investors. The $\mathrm{R}^{2}$ Nagelkerke $=0.628$ means that $62.8 \%$ of the dependent variables are explained by independent variables in the model. On the other hand, the value of $-2 \mathrm{LL}=334.618 \mathrm{a}$ is quite small and the high probability of the model (93.6\%) which indicats the good fit of the analytical model. Moreover, many factors in the model influence statistical significance. From the logistic regression analysis, the regression equation could be writen as follows:

$$
\operatorname{Logit}\left(\mathrm{P} / \mathrm{Y}_{\mathrm{i}}=1 / \mathrm{X}_{\mathrm{i}}=\mathrm{X}_{\mathrm{i}}\right)=-19.460+1.219 \times \mathrm{I}+1.215 \times \mathrm{N}+3.042 \times \mathrm{CP}+0.769 \times \mathrm{PS}
$$

We have the probability to decide:

$$
\mathrm{E}(\mathrm{Y} / \mathrm{X})=\frac{\mathrm{e}^{(-19.460+1.219 \times \mathrm{I}+1.215 \times \mathrm{N}+3.042 \times \mathrm{CP}+0.769 \times \mathrm{PS}}}{1+\mathrm{e}^{(-19.460+1.219 \times \mathrm{I}+1.215 \times \mathrm{N}+3.042 \times \mathrm{CP}+0.769 \times \mathrm{PS}}}
$$

If an investor evaluates the factors as follows: $\mathrm{I}=3 ; \mathrm{N}=4 ; \mathrm{CP}=3 ; \mathrm{PS}=3$. We have: $\mathrm{E}(\mathrm{Y} / \mathrm{X})=0.6628$ or $66.28 \%$. The model indicates that the investor's ability to invest is $66.28 \%$. Assuming that the initial investment decision probability $\left(\mathrm{P}_{0}\right)$ is $10 \%$, when other factors are remained constant, the probability of the change in investment decision $\left(\mathrm{P}_{1}\right)$ of the factors is greater, demonstrating the role of the factor that affects the ability to attract capital and it is calculated according to the following formula:

$$
\mathrm{P}_{1}=\frac{\mathrm{P}_{0} \times \mathrm{e}^{\mathrm{Bi}}}{1-\mathrm{P}_{0}\left(1-\mathrm{e}^{\mathrm{Bi}}\right)}
$$

The results of calculating the probability of changing the investment decision and the position of influence of the factors are shown in the following table: 
Table 4

\begin{tabular}{|c|c|c|c|c|c|c|}
\hline No & Variable & B & EXP(B) & $\begin{array}{c}\text { Initial probability } \\
\mathrm{P}_{0}=10 \% \\
\mathrm{P}_{1}(\%)\end{array}$ & $\begin{array}{l}\text { Speed of increase } \\
\text { (decrease) } \%\end{array}$ & $\begin{array}{l}\text { Position of } \\
\text { influence }\end{array}$ \\
\hline 1 & I & 1.219 & 3.384 & 27.33 & 17.33 & 2 \\
\hline 2 & $\mathrm{~N}$ & 1.215 & 3.371 & 27.25 & 17.25 & 3 \\
\hline 3 & $\mathrm{CP}$ & 3.042 & 20.956 & 69.96 & 59.96 & 1 \\
\hline 4 & PS & .769 & 2.158 & 19.34 & 9.34 & 4 \\
\hline
\end{tabular}

With $\mathrm{P}_{1}=0.2733$ (27.33\%): When other factors are constant, if the I (infrastructure) is improved by 1 unit, the ability to attract investment capital will be $27.33 \%$ (increase by $17.33 \%$ compared with the initial probability). $\mathrm{P}_{1}=0.2725(27.25 \%)$ : When other factors are constant, if the $\mathrm{N}$ (natural resources) is improved by 1 unit, the ability to attract investment capital will be $27.25 \%$ (increase by $17.25 \%$ compared with the initial probability). $\mathrm{P}_{1}=0.6996(69.96 \%)$ : When other factors are constant, if the CP (capital resources) is improved by 1 unit, the ability to attract investment capital will be $69.96 \%$ (increase by 59.96\% compared with the initial probability). $\mathrm{P}_{1}=19.34 \%$ : When other factors are constant, if the PS (politic-society) is improved by 1 unit, the ability to attract investment capital will be $19.34 \%$ (increase by $9.34 \%$ compared with the initial probability). Thus, in the variables affecting the ability to attract investment capital, the $\mathrm{CP}$ variables have the strongest influence on the decision of investors, the rest are in order: I, N and PS.

\section{Conclusions and policy recommendations}

Based on our regression outputs, in order to help Thanh Hoa province, in order for Vietnam to attract more and more investment capital from domestic and foreign investors for tourism development, it is important to focus on the solutions in which the most important is the group of solutions on mechanisms and policies to attract investment capital of the local. Accordingly, the authors propose a system of policy solutions as follows:

Firstly, localities need to issue policies to support the construction of infrastructure and technology other than tourism projects. This is the factor that most investors consider to have the greatest impact on their investment decisions, specifically as follows:

- Traffic: The provincial budget can support 50\% of the cost of construction of the roads from the main road to the fence of the project in accordance with the design, cost estimates and final settlement approved by the competent authority, but not exceeding 5 billion.

- Electricity, water supply and drainage to the fence of the project: The provincial budget should support $50 \%$ of the expenses of construction of substation, power lines and water supply and drainage to the fences of the project in accordance with the design, cost estimates and final settlement approved by the competent authority, but not exceeding 1 billion VND for all above items.

Secondly, Thanh Hoa authorities need to study and promulgate policies on land support and site clearance for key tourism projects. Results of research on factors influencing investors' decisions when considering investment in Thanh Hoa tourism development show that land and site clearance factors are highly appreciated by investors. It is the second most influential factor in the decision of investors. Therefore, localities need policies to support land, site clearance to the key tourism projects. Specifically, Thanh Hoa province has committed to implement the viewpoint: Investors of tourism projects in the province are entitled to the highest incentives in the framework of the law on land.

In addition to specific site clearance for investment projects in area and destination with tourism development plan, the provincial People's Committee is responsible for directing the sectors and localities together with the investors in order to site clearance in accordance with schedule committed. Provincial People's Committees may consider and partly support the expenses for compensation, support and resettlement. The remaining of compensation, support and resettlement expenses shall be paid by the investors and deducted from the payable land use fees or land rents and it is complied with the current law provisions.

Thirdly, in addition to policies on investment in infrastructure construction, technical outside the fence of tourism projects and policies on land support and site clearance for key tourism projects, policies on taxes, fees and charges are also interested to investors. Specifically, investors want to be exempted from tax for 4 years, $50 \%$ reduction of tax payable in the next 9 years for newly established tourism enterprises from investment projects in class A area, the preferential tax rate of $10 \%$ are applied for 15 years. Tax exemption for two years, $50 \%$ reduction of the tax payable in the next four years for newly established tourism enterprises from investment projects in class B area, the preferential tax rate of $20 \%$ are applied for 10 years. In addition, the province can offer tax policies to local enterprises based on seniority. Accordingly, the enterprises attached to the local in longterm, based on the number of years invested in the local, it will be supported at a certain tax. The specific calculation method should be written and widely advertised to the business community and mass media.

Fourthly, Thanh Hoa province should have policies to support human resource development and research and application to improve the quality of Thanh Hoa tourism products. In order to attract investors in general and especially investors in particular, 
in the future, Thanh Hoa needs to effectively implement human resource training program to meet the development requirements of socio-economic situation and the demand of the local labor market.

Fifthly, localities should also pay attention to the issuance of credit policies to support local tourism development projects because they are always important factors for investors in general as well as investors in the tourism sector in particular. Therefore, an important content that local government needs to support investors in Thanh Hoa is to have a specific policy on credit for tourism projects. Specifically, projects on investing ships and boats to transport tourists by water: investment, procurement of new ships with a capacity of installing 150 seats or more are facilitated to borrow capital with preferential interest rates; In case of inability to borrow preferential capital and having to borrow capital from commercial banks, the provincial budget shall support $3 \%$ of the loan interest rate within 36 months from the date of repayment under the credit contract. The maximum support level must not exceed VND 200 million/project. Moreover, investment projects in the tourism sectors under this regulation are given priority by the Development Bank and the Social Policy Bank to provide loans for investment in accordance with the regulations.

Sixthly, in addition to the proposed price policies, Thanh Hoa province should consider implementing the social value strategy. Local authorities should also have policies to support organizations and individuals who have achievements in mobilizing investment projects in the field of tourism. Apart from being rewarded according to the current regulations of the State, provincial budgets will be rewarded from 100 million VND to 500 million VND depending on the scale of the project (Not applicable to the following subjects: state agencies, socio-political organizations and public non-business units using the state budget for operation. According to the policies to attract tourism investment in Thanh Hoa province as above, Thanh Hoa province will use price means to attract investment and take the criteria for social benefits to send messages to investors. Investors who benefit from this price strategy will have to be able to bring many social benefits to Thanh Hoa province, in which employment and reinvestment for urban upgrade are improved. That is the number one priority.

\section{References}

Anh, T., Hanh, P., Cam, L., Van, K., \& Dinh, L. (2019). A study of the factors affecting the content created by international travellers in Vietnam. Management Science Letters, 9(12), 2051-2062.

Anh, T., Diem, C., Cam, L., \& Viet, T. (2020). Exploring factors influencing on organizational repurchases intention in B2B tourism context. Management Science Letters, 10(3), 531-542.

Donwa, P., \& Odia, J. (2010). An empirical analysis of the impact of the Nigerian capital market on her socio-economic development. Journal of Social Sciences, 24(2), 135-142.

Dunning, J. H. (1997). A business analytic approach to governments and globalization. Governments, globalization, and international business, 114-131.

Ewah, S. O., Esang, A. E., \& Bassey, J. U. (2009). Appraisal of capital market efficiency on economic growth in Nigeria. International Journal of Business and Management, 4(12), 219-225.

Gilmore, A., O'Donnell, A., Carson, D., \& Cummins, D. (2003). Factors influencing foreign direct investment and international joint ventures: A comparative study of Northern Ireland and Bahrain. International Marketing Review, 20(2), 195-215.

Gupta, A. K., Sinha, R., Koradia, D., Patel, R., Parmar, M., Rohit, P., ... \& Chandan, A. (2003). Mobilizing grassroots' technological innovations and traditional knowledge, values and institutions: articulating social and ethical capital. Futures, 35(9), 975-987.

Ha, N. K. G., Le, Q. H., \& Nguyen, T. C. H. (2013). Survey on the factors that attract investment capital in Quang Tri province. Journal of Science, Dong Thap University, 3(6), 19-30.

Le, H.B.H., Nguyen, T.H. (2017). Determination of factors affecting the attraction of investment capital beyond the state budget for tourism development in Thanh Hoa province. Journal of Economics and Development, 242(2).

Nguyen, M. T. (2010). Factors influencing the attraction of foreign direct investment into one locality of Vietnam. Journal of Science \& Technology, University of Da Nang, 5(40), 270-276.

Nguyen, T., Nguyen, N., \& Nguyen, V. (2019a). Identifying factors influencing on the profitability of tourist enterprises: Evidence from Vietnam. Management Science Letters, 9(11), 1933-1940.

Nguyen, V., Nguyen, T., Tran, T., \& Nghiem, T. (2019b). The impact of financial leverage on the profitability of real estate companies: A study from Vietnam stock exchange. Management Science Letters, 9(13), 2315-2326.

Nunnally, J. C. (1994). Psychometric theory 3E. Tata McGraw-Hill Education.

Rankin, K. N. (2002). Social capital, microfinance, and the politics of development. Feminist economics, 8(1), 1-24.

Tran, T., Phi, T., Tran, M., \& Hoang, V. (2019). Economic linkage in key economic zones: The case of Vietnam. Management Science Letters, 9(3), 443-456.

Tung, L. (2019). Does exchange rate affect the foreign tourist arrivals? Evidence in an emerging tourist market. Management Science Letters, 9(8), 1141-1152.

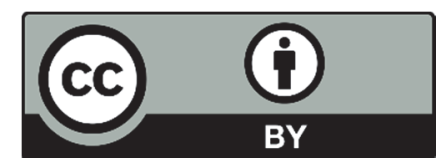

(C) 2020 by the authors; licensee Growing Science, Canada. This is an open access article distributed under the terms and conditions of the Creative Commons Attribution (CC-BY) license (http://creativecommons.org/licenses/by/4.0/). 